\title{
India pledges to fund alert system in wake of disaster
}

India's government and scientific establishment have been heavily criticized for failing to provide warning of a tsunami that drowned at least 12,000 people on the nation's eastern coast.

Newspapers and opposition spokesmen have asked why a country with India's scientific resources couldn't better prepare for such an event. Ministers immediately pledged up to US\$29 million to build a tsunami-monitoring system, and promised to seek more cooperation with the Pacific Tsunami Warning Center in Hawaii.

"This is not a knee-jerk reaction. We are very serious," science and technology secretary Valangiman Ramamurthi told Nature. "We are going to have a brain-storming meeting this month to decide how we should proceed and we have invited experts from the United States," he said. In response to criticism, he added: "We cannot join a Pacific network as India is not in that region. And you do not make heavy investment to warn against something that happens once in a century."

The ocean development secretary, Harsh Gupta, told a press conference in New Delhi

ITSU. "We expected a local tsunami at most."

At 2:04 GMT, the PTWC put out another bulletin revising the quake up to magnitude 8.5. Because there was no information about sea levels in the area, the existence of a tsunami was merely hypothetical, but staff were worried enough to begin looking for numbers to call in Asia.

\section{Communication breakdown}

According to Kong, the team tried and failed to reach colleagues in Indonesia. Australia was contacted, although to little avail, as that country experienced only half-metre waves. It was not until 3:30 that the team in Hawaii saw news reports on the Internet of casualties in Sri Lanka. The wave had already crossed the ocean, to devastating effect.

Kong says that without a predetermined communication plan, warning efforts were doomed from the start. But she adds that the PTWC will in future directly contact the US state department, which can communicate risks to any nation, at any time.

Indonesian seismologists initially underestimated the strength of the earthquake, according to local news reports. And although officials there had very little time in which to act, an instrument that could have helped warn them of the approaching wave was transmitting its information to a dead phone line, according to a senior Indonesian seismologist (see news@nature.com doi:10.1038/news041229-4;2004).

Efforts over the years to get an Indian Ocean warning system in place have made little progress in the face of national governments' reluctance to invest in them. In 2003, a working group on the Tsunami Warning System in the Southwest Pacific and Indian

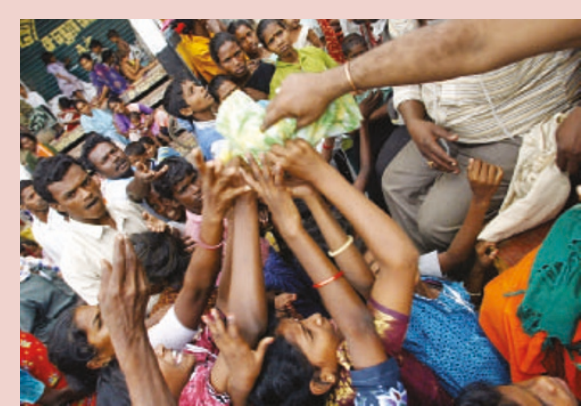

Relief centres in India have been inundated with people in need of food and aid.

that there was no record of a tsunami ever hitting the Indian coastline, even as other government ministers acknowledged such events in 1833 and 1883.

"No government thought of it," says science minister Kapil Sibal. "The last recorded tsunami was in 1883. It was not in the horizon of our thoughts." India now plans to install a network of 10 to 12 seafloor pressure sensors to be imported from the United States, as well as several floating

Ocean was established within ITSU. But Pissierssens says that the first chair of the group, a representative from Indonesia, left soon after his appointment and that the group then split into two according to region.

Phil Cummins a seismologist at Geoscience Australia in Canberra agreed to write a position paper for the group on tsunami risk in the Indian Ocean. "I am still in the process of writing that paper," he says. "No one else was $100 \%$ convinced that we should worry and that included me, I've got to admit."

According to Pissierssens, UNESCO will now make an observation system in the Indian Ocean a priority. "The first thing we will do is send out a survey team in January or February," he says, "and then we want to set up sensors on ocean buoys, linked to an Indian geostationary satellite.

Critics say that the tragedy exposed a major weakness in the current system, which authorizes only the Indian Meteorological Department to put out hazard alerts. "Data were pouring into our lab but we cannot issue alerts even if we can analyse the data for tsunami potential," says one researcher at the National Geophysical Research Institute in Hyderabad.

They also want to know why the Indian air force, whose base in Car Nicobar Island was submerged by tides an hour before the waves hit the mainland, failed to provide any public warning.

The tsunami spared India's main rocket launch site at Sriharikota Island, 80 kilometres north of Chennai. But it damaged cooling water pumps at a nuclear power station at Kalpakkam, leaving staff with very little time to shut down the plant safely. "The tsunami factor was not taken into account," says Anil Kakodkar, chairman of the Atomic Energy Commission. "From now on, it will be

factored in."

K. S. Jayaraman, New Delhi

a conference in the area." Needless to say, there is little reluctance now to accept the need for the system. The UN International Strategy for Disaster Reduction has also said that one should be built within a year. And the Indian government, under intense domestic pressure for its failure to warn people on its eastern coast, said it would spend up to US\$29 million to build a system itself (see 'India pledges to fund alert system in wake of disaster', above).

Nicole Rencoret, spokeswoman for the UN's disaster-reduction branch, notes that early warning systems could watch for other natural disaster risks, as well as tsunamis. "There has been an enormous amount of focus on tsunamis, but we need to take a multihazard approach," she says.

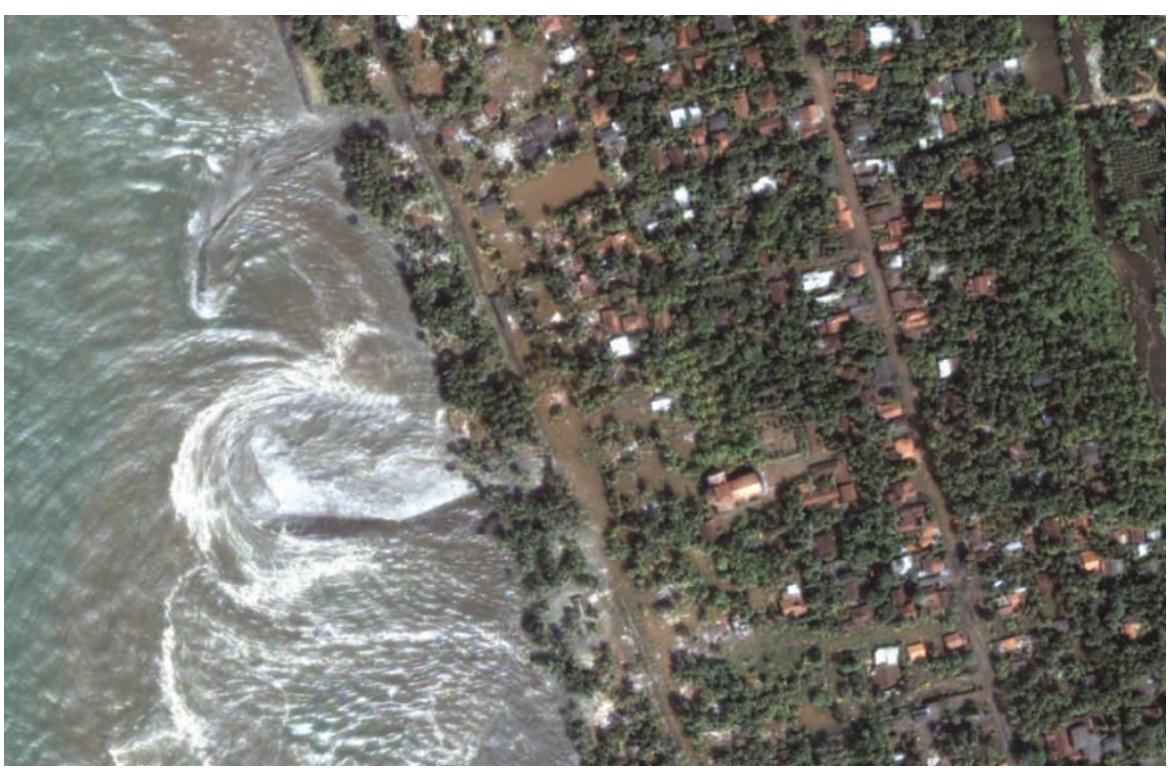

Turning tide: the waters of the Indian Ocean tsunami recede after battering the coast of Sri Lanka. 